\title{
Effect of binder type and content on physical and mechanical properties of geopolymers
}

\author{
NIYAZI UGUR KOCKAL*, OZGE BEYCAN and NIHAN GULMEZ \\ Department of Civil Engineering, Akdeniz University, 07058 Antalya, Turkey \\ e-mail: ukockal@yahoo.com; beycan.ozge@gmail.com; nihanglmz@gmail.com
}

MS received 9 March 2017; revised 29 October 2017; accepted 22 November 2017; published online 4 April 2018

\begin{abstract}
In this study, the physical and mechanical behaviors of geopolymers prepared by using different amounts of silica fume and calcium hydroxide as binding materials, acidic pumice as fine aggregate and waste aluminium particles as air-entraining agent were investigated. Test results showed that binder types, amount of binders and alkali activator (sodium hydroxide) significantly affected the physical and mechanical behavior of geopolymer specimens. Bulk density, compressive and flexural strength decreased with the higher alkali activator content. Addition of waste aluminium particles led to decrease in bulk density and strength due to the some extent of entrained air. In the case of same alkali activator content, compressive and flexural strength increased with increase in silica fume and calcium hydroxide up to a certain level.
\end{abstract}

Keywords. Alkali activator; geopolymer; binder; waste aluminium particles.

\section{Introduction}

Geopolymer, a new environment friendly inorganic binder has attracted significant attention in recent years as a practical alternative to Portland cement [1]. Geopolymer binders can reduce $\mathrm{CO}_{2}$ emissions by $80 \%$ compared to ordinary Portland cement [2]. Geopolymers are a class of materials consisting of an amorphous, three-dimensional structure synthesized by alkaline activation of an aluminosilicate source at ambient or higher temperature through a geopolymerization process [3]. Geopolymerization process relies on the reaction of silica and alumina with high alkali solution. The constituents can be industrial or agricultural by-products having reactive silica and/or alumina [4]. These aluminosilicate reactive materials are rapidly dissolved in strong alkaline solution resulting in formation of free $\mathrm{SiO}_{4}$ and $\mathrm{AlO}_{4}$ tetrahedral units. Geopolymer products can be formed by yielding polymeric precursors resulting from linking alternatively of these $\mathrm{SiO}_{4}$ and $\mathrm{AlO}_{4}$ tetrahedral units with the development of reaction [5]. Unlike ordinary Portland cement, geopolymers do not require calcium-silicate-hydrate $(\mathrm{C}-\mathrm{S}-\mathrm{H})$ gel for matrix formation and strength, but utilise the polycondensation of silica and alumina precursors to achieve the required strength level [6].

Silica fume (SF) is one of the common mineral admixtures with high pozzolanic reactivity and micro-aggregate filling effect [7, 8]. Silica fume and other pozzolanic materials contain a high active $\mathrm{SiO}_{2}$ which is able to cause a reaction with $\mathrm{Ca}(\mathrm{OH})_{2}[9,10]$.

*For correspondence
The use of silica fume can significantly enhance mechanical properties of concrete/mortar given its beneficial filling and pozzolanic effects $[11,12]$. The strength enhancement in the cement composites incorporated with silica fume is due to pore size refinement and matrix densification, reduction of $\mathrm{Ca}(\mathrm{OH})_{2}$ content and cement paste-aggregate interfacial refinement [13]. Silica fume can also be used to produce geopolymer products $[14,15]$. Dutta et al [16] studied the effect of silica fume additions on porosity of fly ash geopolymers. They concluded that addition of silica fume up to $5 \%$ enhanced compressive strength of geopolymer mortars, however, further increase of silica fume caused a decrease in compressive strength. They also stated that SEM micrographs for specimens incorporated with silica fume showed better microstructure and exhibited lesser porosity. Mijarsh et al [17] found that the mechanical properties of treated palm oil fly ash (TPOFA)-based geopolymer mortar were enhanced by $75.21 \%$ at 28 days when TPOFA was substituted with $\mathrm{Ca}(\mathrm{OH})_{2}$ and modified with two other additives $\left[\mathrm{Al}(\mathrm{OH})_{3}\right.$ and silica fume]. It was observed that the type of gel formed $(\mathrm{N}-\mathrm{A}-\mathrm{S}-\mathrm{H}$ and/ or $\mathrm{C}-\mathrm{S}-\mathrm{H}$ ) was directly dependent on the initial chemical compositions of the mixture.

Yang et al [18] stated that the different mechanical properties of $\mathrm{Ca}(\mathrm{OH})_{2}$-based alkali-activated ground granulated blast-furnace slag concrete were commonly dependent on its compressive strength and those correlations were similar to the trend generally observed in OPC concrete. Vargas et al [19] indicated that mixes with higher $\mathrm{Ca}(\mathrm{OH})_{2}$ contents may exhibit high compressive strength at 
Table 1. Chemical composition of silica fume.

\begin{tabular}{lccccccccccc}
\hline Oxide & $\mathrm{SiO}_{2}$ & $\mathrm{Al}_{2} \mathrm{O}_{3}$ & $\mathrm{MgO}$ & $\mathrm{Na}_{2} \mathrm{O}$ & $\mathrm{K}_{2} \mathrm{O}$ & $\mathrm{SO}_{3}$ & $\mathrm{CaO}$ & $\mathrm{Fe}_{2} \mathrm{O}_{3}$ & $\mathrm{ZnO}_{2}$ & $\mathrm{Cr}_{2} \mathrm{O}_{3}$ \\
\hline Silica fume & 89.11 & 1.00 & 2.74 & 1.18 & 0.80 & 0.45 & 1.11 & 0.45 & 0.52 & 2.31 \\
\hline
\end{tabular}

earlier ages, but a reduction in strength would occur over time. They also concluded that this mechanical behavior was probably related to changes to the internal structure of the alkali-activated matrix, resulting in reduction of strength.

In the work of Reig et al [20] porcelain stoneware were activated by alkali solutions. The activator concentration and calcium hydroxide addition noticeably influenced the fresh behavior of mortars causing a suitable workability and setting time. Alonso and Palomo [21] investigated the effect of the metakaolin/ $\mathrm{Ca}(\mathrm{OH})_{2}$ ratio on specimens prepared with metakaolin with two different $\mathrm{Ca}(\mathrm{OH})_{2}$ contents $(30-50 \%)$. It is stated that in the presence of calcium hydroxide and high alkaline solution concentrations, metakaolin activation took place leading to sodium aluminosilicate as a reaction product.

The literature studies revealed the limited investigations about combinations of silica fume and calcium hydroxide as binders on the properties of geopolymers. In addition, although waste materials with different origins have been studied as air-entraining agents, any study on waste aluminium particles has not been encountered in literature survey. The present work aims to determine the physical and mechanical behavior of geopolymer mortar produced by using silica fume and calcium hydroxide as binders, waste aluminium particles as air-entraining agent and acidic pumice as fine aggregate. The effects of amount of binders, binder types, and alkali activator/solid ratio on air- entrained and non-entrained geopolymers were investigated.

\section{Experimental procedures}

\subsection{Materials}

Specific gravity of the calcium hydroxide $\left(\mathrm{Ca}(\mathrm{OH})_{2}\right)$ was 2.35 . The chemical composition of silica fume obtained by X-ray fluorescence (XRF) is given in table 1 . The specific gravity of silica fume was 2.25. Acidic pumice aggregate was used as fine aggregate with a specific gravity of 2.13. Loose and rodded unit weight of acidic pumice aggregates tested in oven-dry condition using the shoveling and rodding procedure to determine the unit weight and void content according to ASTM C 29-97 [22] were $1.26 \mathrm{~g} / \mathrm{cm}^{3}$ and $1.38 \mathrm{~g} / \mathrm{cm}^{3}$, respectively. Particle size distribution of the acidic pumice aggregate determined in accordance with TS 3530 EN 933-1 [23] is given in figure 1. Al-particles were obtained as waste from metal processing and forming industry. Al-particles as $0.01 \%$ by weight of total mixture were used to create air- entraining in geopolymer. The specific gravity of Al-particles was 2.71. Sodium hydroxide $(\mathrm{NaOH})$ with more than $99 \%$ purity was used as an alkali activator. Molecular weight of activator is $40 \mathrm{~g} / \mathrm{mol}$. The amount of $\mathrm{Na}_{2} \mathrm{CO}_{3}$ in activator is less than $1 \%$. Chloride and $\mathrm{SO}_{4}$ amount in activator are less than $0.0005 \%$. $\mathrm{Al}$ and $\mathrm{Fe}$ contents of activator are less than $0.0005 \%$.

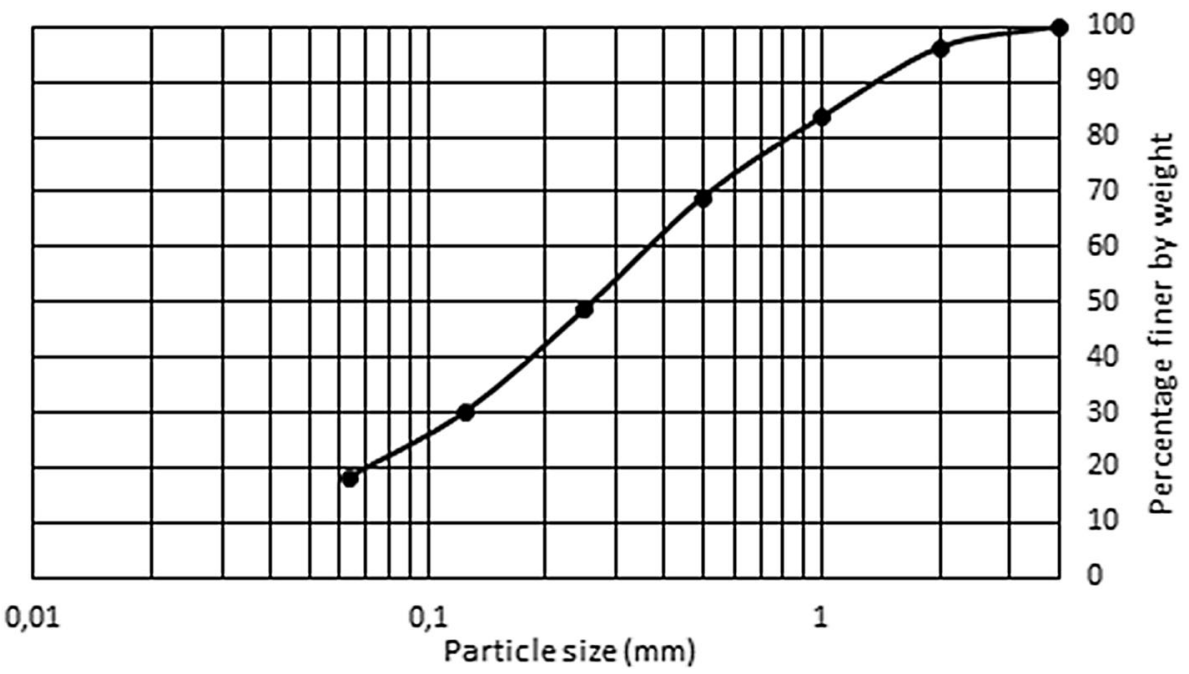

Figure 1. The particle size distribution of the acidic pumice aggregate. 
Table 2. Mix design of geopolymer specimens (by volume, $\mathrm{dm}^{3} /$ $\left.\mathrm{m}^{3}\right)$.

\begin{tabular}{lcrcc}
\hline Mix & $\begin{array}{c}\text { Alkali } \\
\text { activator }\end{array}$ & $\begin{array}{c}\text { Silica } \\
\text { fume }\end{array}$ & $\begin{array}{c}\text { Acidic } \\
\text { pumice }\end{array}$ & $\begin{array}{c}\text { Calcium } \\
\text { hydroxide }\end{array}$ \\
\hline S1 & 400 & 50 & 350 & 200 \\
S2 & 400 & 100 & 350 & 150 \\
S3 & 400 & 100 & 400 & 100 \\
S4 & 400 & 150 & 400 & 50 \\
S5 & 450 & 50 & 350 & 150 \\
S6 & 450 & 100 & 350 & 100 \\
S7 & 450 & 50 & 400 & 100 \\
S8 & 450 & 100 & 400 & 50 \\
\hline
\end{tabular}

\subsection{Mixing procedure and the preparation of the geopolymer mortars}

Geopolymer mixes were produced as follows: sodium hydroxide pellets were dissolved in water to prepare an alkali solution. The cost is one of the important parameters to select the source materials for making geopolymers. The aim was to reduce cost in order to increase competitiveness in practice. Therefore, concentration of the sodium hydroxide solution was kept minimum and constant as $6 \mathrm{M}$ for all specimens based on the optimal results of the preliminary tests due to its higher cost compared to other constituents. The most suitable duration for mixing steps was selected to provide the time for proper mixing, casting, compacting and finishing for all mixtures. Alkali solution was mixed together with the acidic pumice for $30 \mathrm{~s}$. Calcium hydroxide was added into the mixture and mixed for another $30 \mathrm{~s}$. Silica fume was introduced into the mixture and mixed for a further $180 \mathrm{~s}$. Lastly, aluminium particles were added into the mixtures and mixed for $60 \mathrm{~s}$.

Sixteen different types of geopolymer mixes were prepared. Their mix proportions and notations are shown in table 2. Letter "A" was added at the end of the notation of specimens which included waste aluminium particles. The specimens were cast in $40 \times 40 \times 160 \mathrm{~mm}$ metal molds using a vibration table in order to evacuate entrapped air.
The evaporation of water was prevented by sealing the top of the molds with a thin plastic layer during storage. The specimens were demoulded after attaining sufficient hardness to handle them. Demoulded specimens were then immersed in a curing tank at $60^{\circ} \mathrm{C}$ for $24 \mathrm{~h}$, after immersion period, they were transferred to a controllable room maintained at $50 \% \mathrm{RH}$ and $23^{\circ} \mathrm{C}$ for 27 days. A remarkable change in the properties of the specimens could not be observed after that period. Therefore, all tests were performed on 28-day cured specimens.

\subsection{Experimental Investigation}

The bulk density and water absorption values were obtained by testing $40 \times 40 \times 160 \mathrm{~mm}$ prism specimens according to ASTM C 642 [24]. Thermal conductivity coefficient values of geopolymers were also determined by the guarded hot plate method by using a commercial device according to ASTM C 177 [25].

The flexural and compressive strength of hardened mortar specimens were determined in accordance with TS EN 1015-11 [26]. The flexural strength of a hardened mortar was evaluated by three point loading of a $40 \times 40 \times 160 \mathrm{~mm}$ prism specimen, subsequent to the failure and breakage of this specimen, the compressive strength was determined on each half of the prism specimen (figure 2).

When the measurement variation was high, the tests were repeated. Thus, for the accuracy of material characterization test results in the study are given as the average of at least three specimens.

\section{Results and discussions}

The properties of hardened specimens such as porosity and strength are noticeably affected by their features at fresh state such as alkali activator-to-binding materials ratio, setting time and/or workability. The visual examination

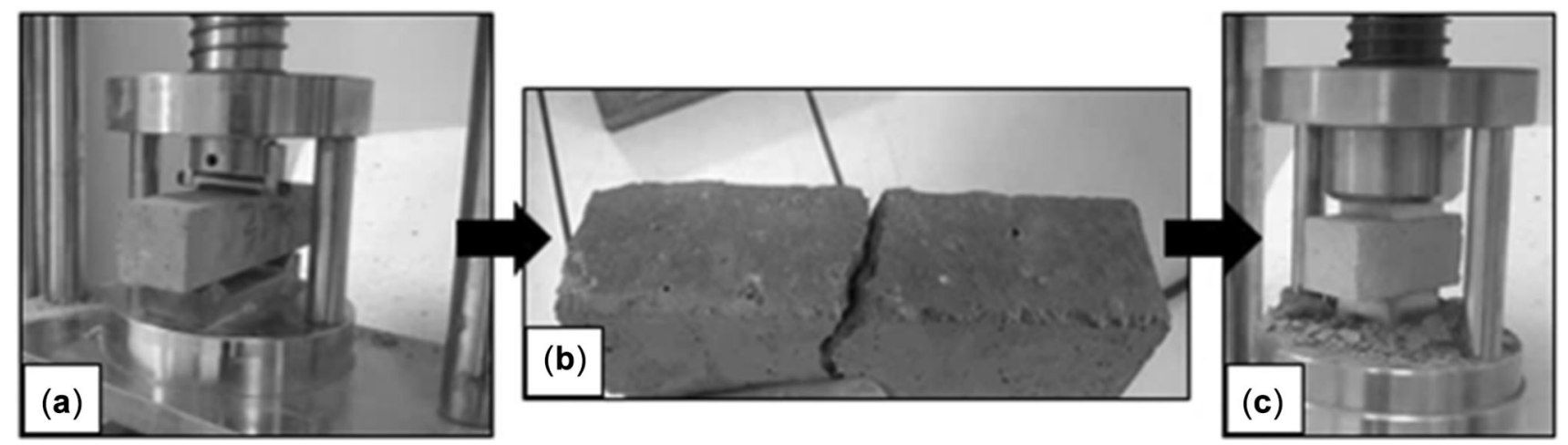

Figure 2. (a) Flexural strength test set-up, (b) broken parts of specimen, (c) compressive strength test set-up. 


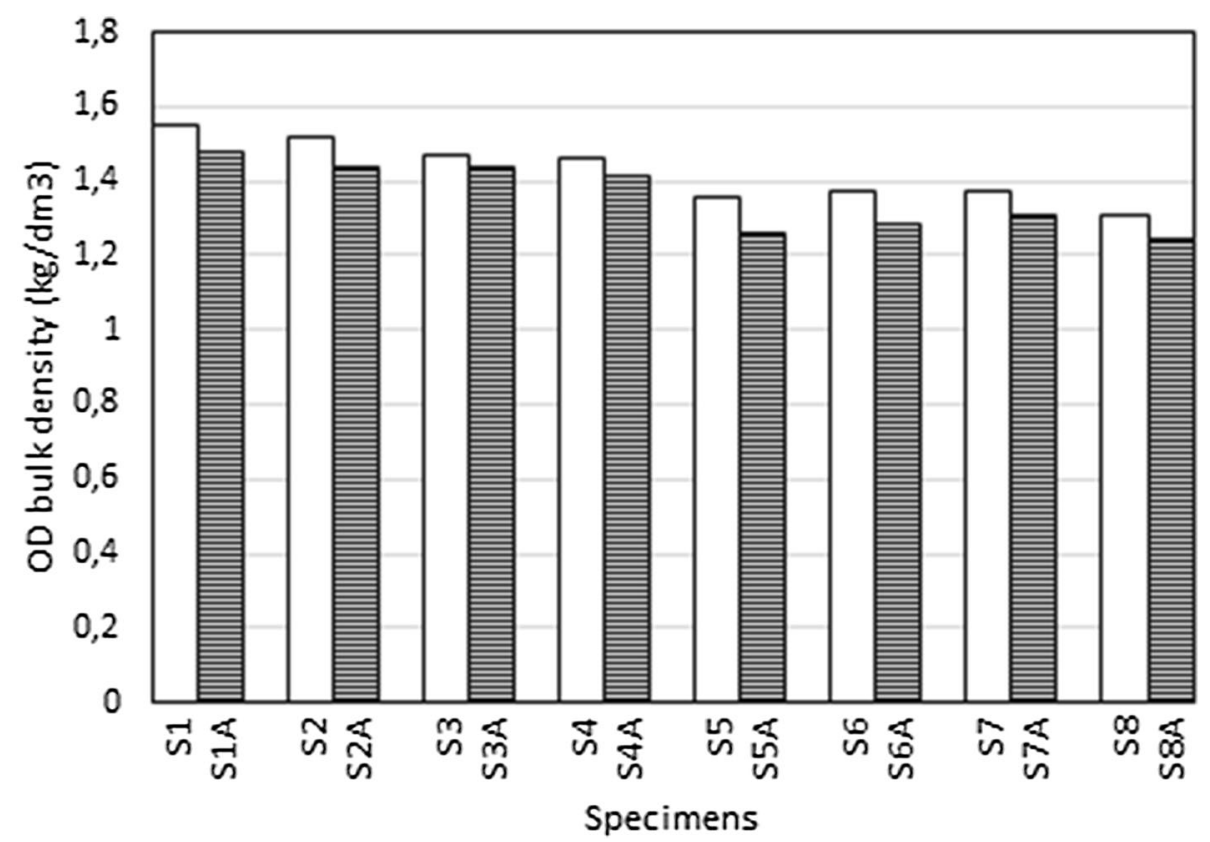

Figure 3. OD bulk density values of specimens.

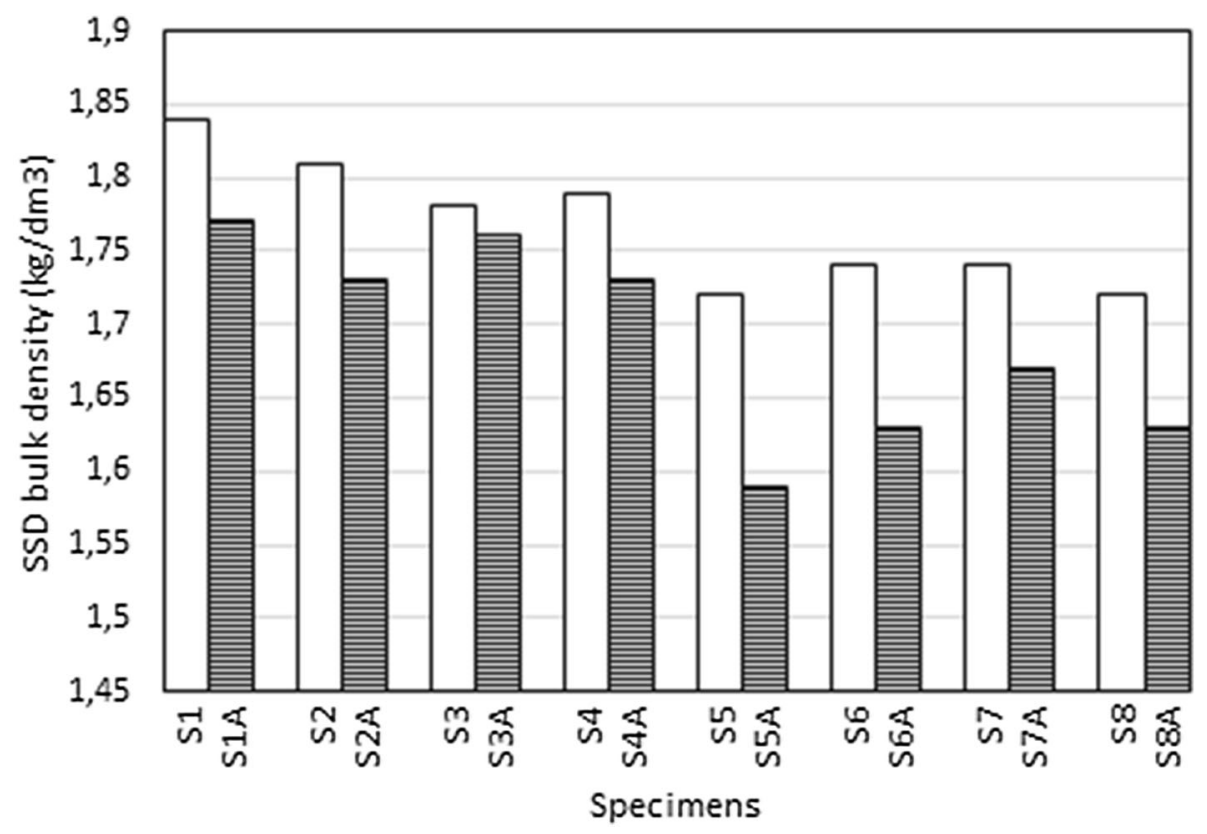

Figure 4. SSD bulk density values of specimens.

demonstrated that the increase of the sodium hydroxide content improved the workability of fresh specimens by providing a proper placement and compaction. In addition, a desirable setting time should be long enough to provide the time for mixing, casting and finishing. However, setting time is also responsible for gaining a sufficient hardness of mixtures. As cast specimens were checked in their moulds, it is revealed that hardening time was prolonged resulting in suitable workability for a longer period of time when amount of sodium hydroxide of specimens increased.

Oven-dry (OD) bulk density, saturated surface dry (SSD) bulk density, water absorption test results of specimens are shown in figures 3, 4 and 5, respectively. Specimens having the ratio of $400 \mathrm{dm}^{3}$ of alkali activator showed OD bulk density varying from 1.41 to $1.55 \mathrm{~kg} / \mathrm{dm}^{3}$ whereas OD bulk density results of specimens having the ratio of $450 \mathrm{dm}^{3}$ of 


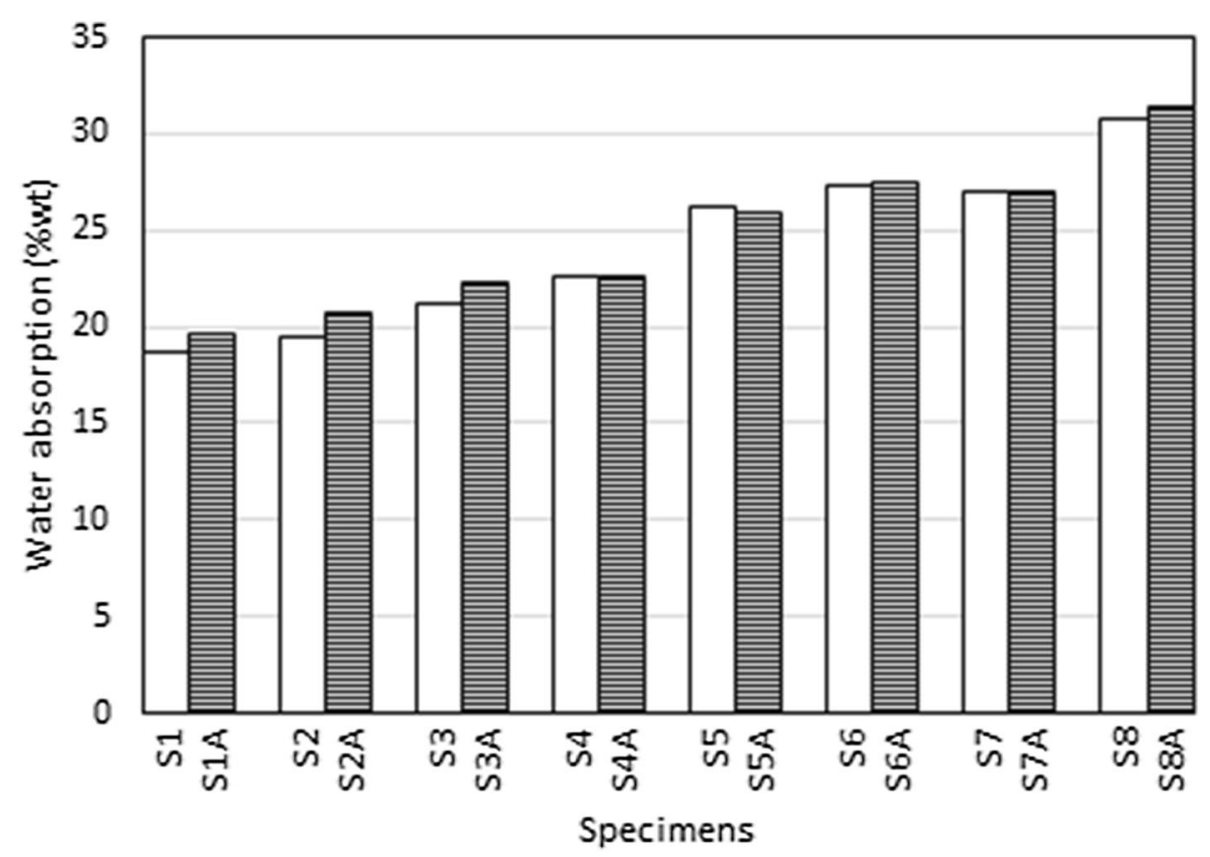

Figure 5. Water absorption ratios of specimens.

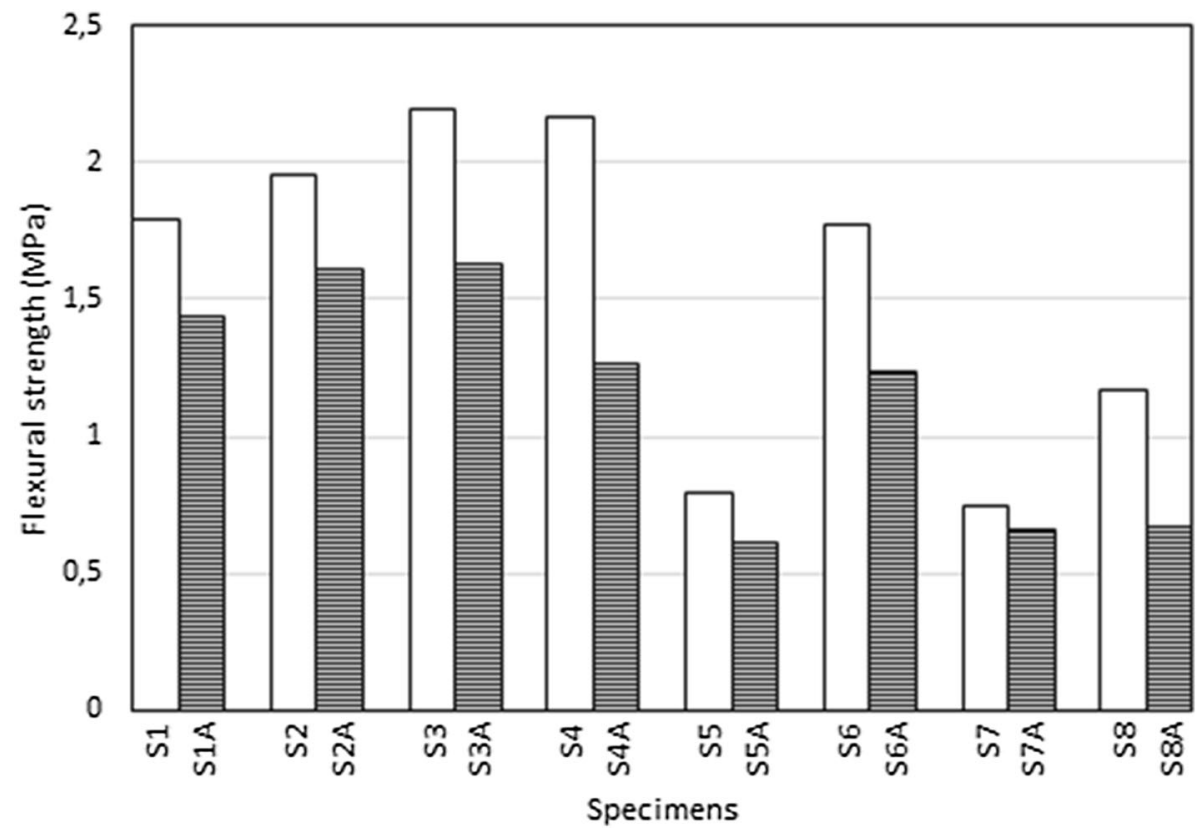

Figure 6. Flexural strength values of specimens.

alkali activator ranging between 1.24 and $1.37 \mathrm{~kg} / \mathrm{dm}^{3}$. S8A specimens had the highest water absorption. However, the lowest OD bulk density was obtained by the same pronounced specimens. In contrast, S1 specimens had the lowest water absorption and the highest OD bulk density. In addition, specimens having the ratio of $400 \mathrm{dm}^{3}$ of alkali activator had the higher OD bulk density and the lower water absorption compared to specimens having the ratio of $450 \mathrm{dm}^{3}$ of alkali activator.
The bulk density values decreased while water absorption enhanced with an increase in alkali activator/solid ratio. Thokchom et al [27] stated that geopolymer mortar specimens manufactured by activation with higher alkali content $\left(\% \mathrm{Na}_{2} \mathrm{O}\right)$ resulted in lower water absorption, apparent porosity and water sorptivity. They also found that the relationship of residual compressive strength with water absorption, apparent porosity and water sorptivity of geopolymer mortar specimens showed similar trends. In the 


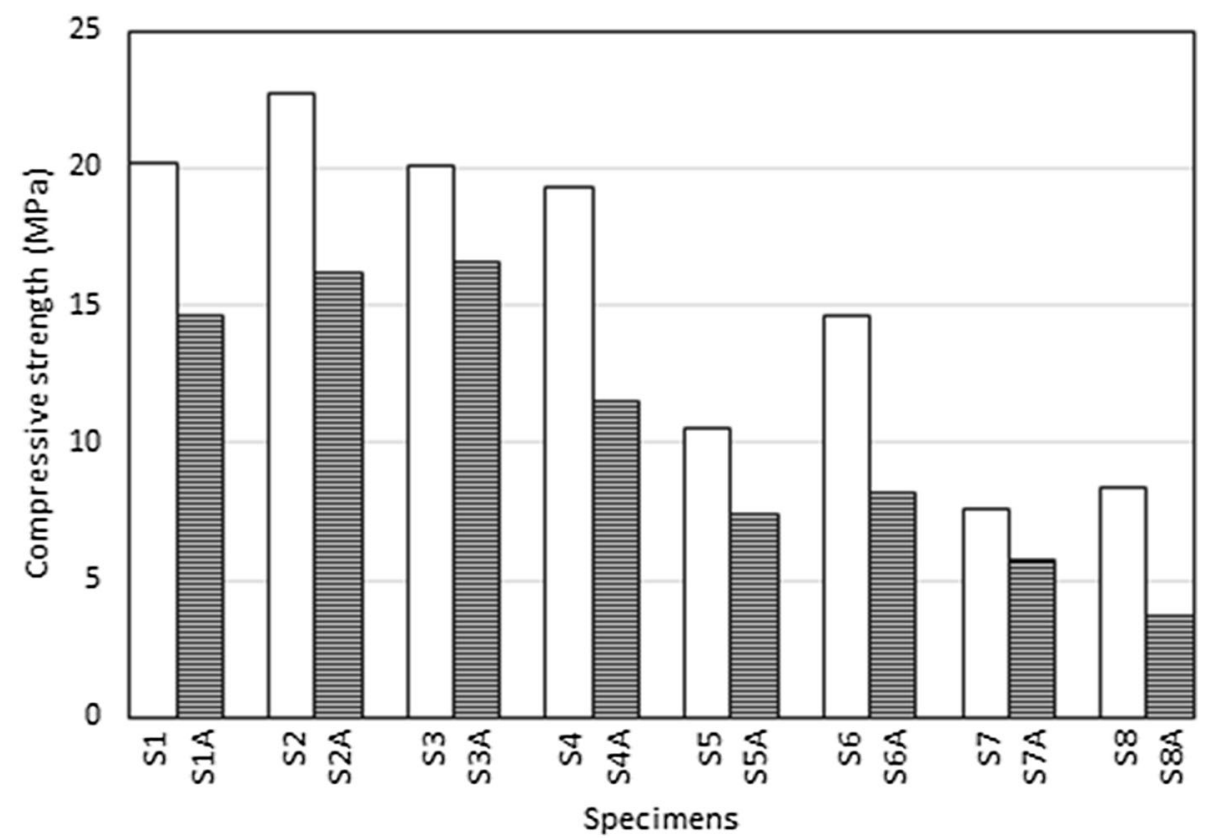

Figure 7. Compressive strength values of specimens.

current study, specimens containing aluminium particles were lighter than specimens without aluminium particles due to having slightly larger air voids. Specimens having same composition with and without Al-particles had similar water absorption ratio. This can be attributed to the gas outlet by reaction of aluminum particles in the mixture, preferring the pores connected with each other to leave the body. Therefore, currently available pores connected with each other resulting in larger channel-like pores without newly emerged voids [28]. Particularly, specimens containing small amounts of calcium hydroxide and large amounts of silica fume and acidic pumice were determined to have low bulk density when the specimens having the ratio of $400 \mathrm{dm}^{3}$ of alkali activator. The reason for this result is the extra gel formation along with the specific weight of the components used.

Figures 6 and 7 give the mechanical properties of specimens. Specimens showed flexural strength varying from

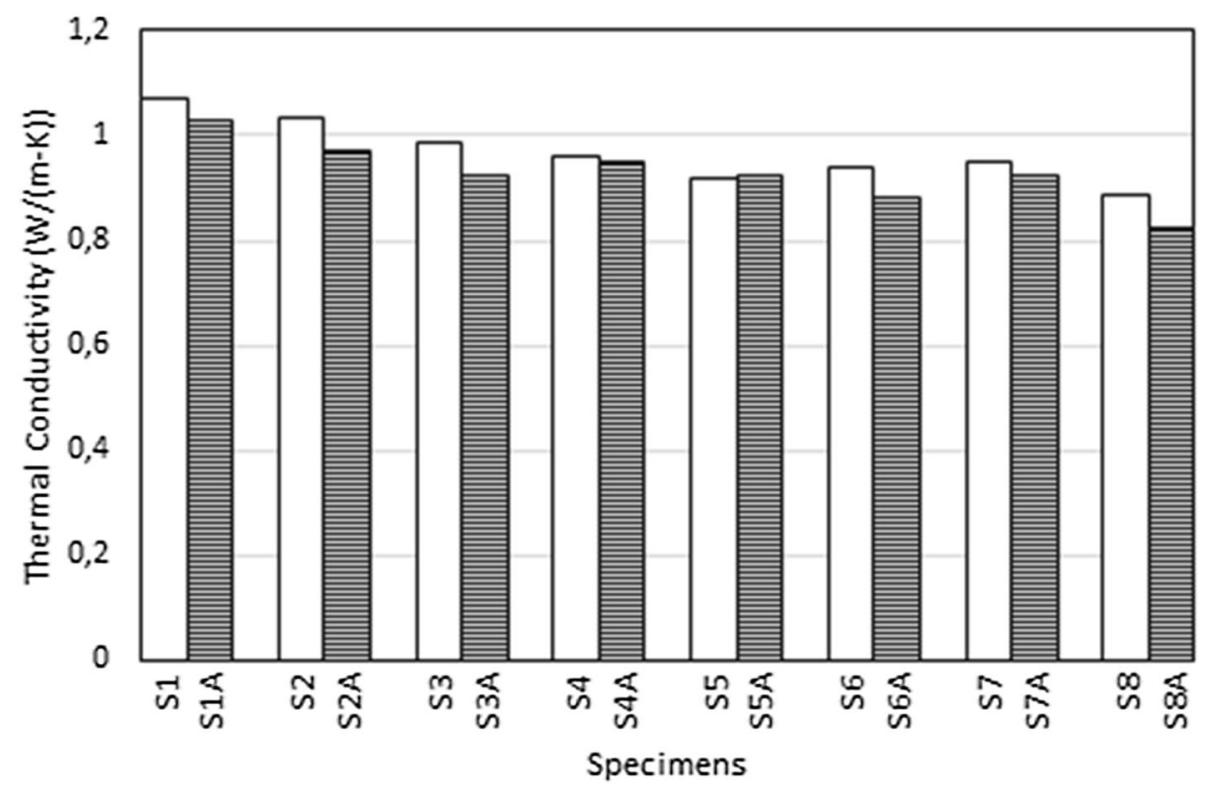

Figure 8. Thermal conductivity coefficients of specimens. 


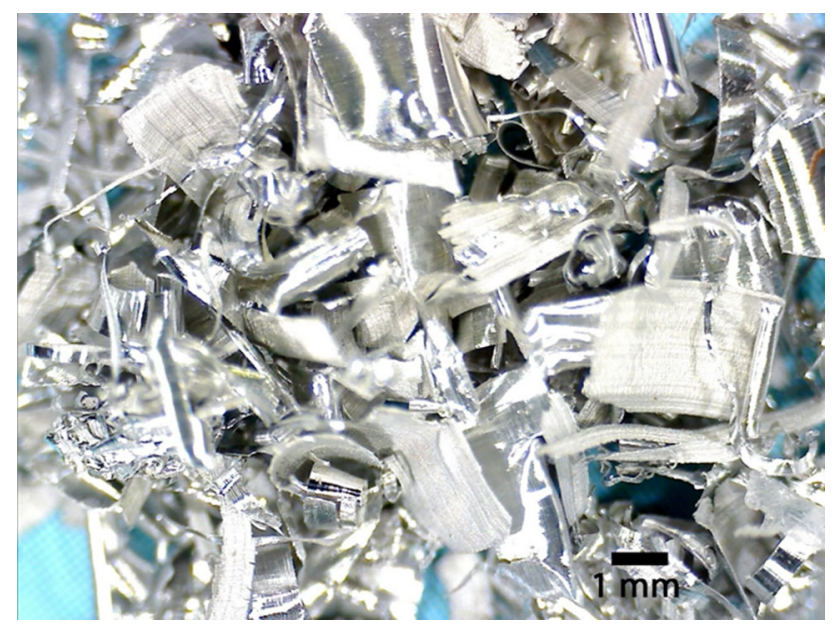

Figure 9. Optical microscope image of Al-particles.

0.61 to $2.19 \mathrm{MPa}$ whereas the differences in compressive strength results were in a wide range varying from 3.68 to 22.75 MPa. However, strength gain in molds for specimens having high alkali activator and pumice contents and low silica fume and calcium hydroxide amounts was very slow, causing a prolonged demoulding time.

A decrease in flexural strength of $19.6 \%, 17.4 \%, 25.6 \%$, $41.9 \%, 22.8 \%, 29.9 \%, 12 \%, 42.7 \%$ for S1A, S2A, S3A, S4A, S5A, S6A, S7A, S8A mixes, respectively was observed according to their non-entrained counterparts. Whereas, a decrease in compressive strength of $27.3 \%$, $28.7 \%, 17.6 \%, 40.6 \%, 29.5 \%, 44.3 \%, 24.8 \%, 56.2 \%$ for S1A, S2A, S3A, S4A, S5A, S6A, S7A, S8A mixes, respectively was observed according to their non-entrained counterparts.

Although the strength was reduced as alkali activator/solid ratio increased, specimens with the same amount of alkali activator did not exhibit a similar trend for the physical properties. Thakur et al [29] found that lower the water content in the mix, higher was the compressive strength. However, further decrease in water content reduced compressive strength. Patankar et al [30] indicated that the compressive strength of geopolymer concrete decreased with increase in water-to-geopolymer binder ratio by changing the quantity of water. In the present investigation, although strength increased with the increase of silica fume in the mixture up to a certain content, strength decreased with the decrease of calcium hydroxide when keeping the silica fume amount constant. However, preliminary test results showed that calcium hydroxide addition higher than $150 \mathrm{dm}^{3} / \mathrm{m}^{3}$ with $450 \mathrm{dm}^{3} / \mathrm{m}^{3}$ of alkali activator content led to significant strength reduction. Rashad et al [31] studied the elevated temperature performance of alkali-activated ground granulated blast-furnace slag/silica fume. They concluded that the optimum proportion of silica fume in alkali-activated slag matrix that gave the highest compressive strength was found to be $5 \%$ silica fume. Similar findings were also reported by Rattanasak and Chindaprasirt [32].

Owing to the reduction in dosage of binders with an increase in acidic pumice by volume in the mixture, strengths were also reduced gradually. Despite acidic pumice having fine grain size and a certain amorphous structure contributing to reactivity, the results were not in support of this case. In other words, acidic pumice behaved as a non-reactive inert porous material. Silica from acidic pumice and silica fume and calcium from lime led to different types of gel formation. Previous study [33] using synthetic gels explored the effects of the constituents of each gel. Researchers found that $\mathrm{C}-\mathrm{S}-\mathrm{H}$ composition was extremely affected by high $\mathrm{pH}$ conditions and the presence of aqueous aluminate and a partial replacement of sodium with calcium to form $(\mathrm{N}, \mathrm{C})-\mathrm{A}-\mathrm{S}-\mathrm{H}$ gels resulted from

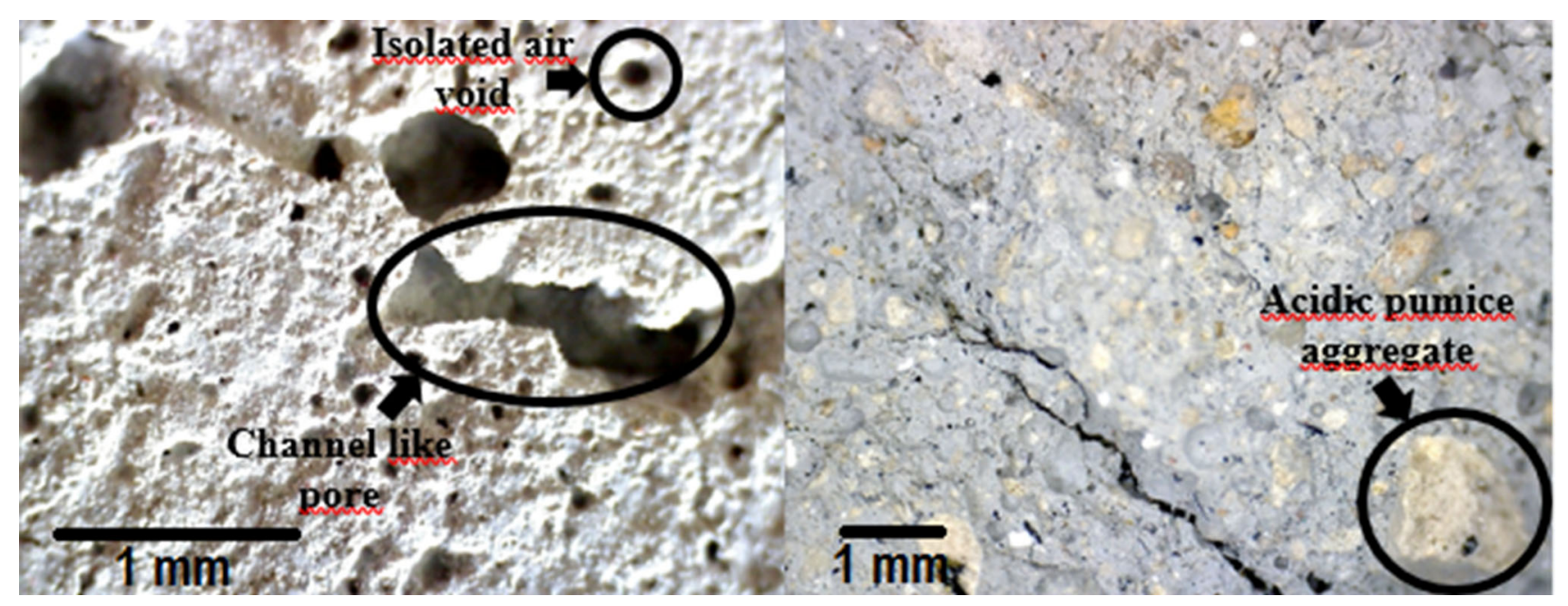

Figure 10. Images of specimens having pumice aggregates and Al-particles with high alkali activator content. 
$\mathrm{N}-\mathrm{A}-\mathrm{S}-\mathrm{H}$ gels modified by aqueous $\mathrm{Ca}$. Increase in the $\mathrm{C}-$ $\mathrm{S}-\mathrm{H}$ was mainly responsible for the strength improvement of the sample with addition of up to $3.75 \%$ silica fume [13]. Refinement of the pore size by addition of silica fume led to higher amount of small pore and higher cumulative pore volume.

The thermal conductivity coefficients were also determined and the results are presented in figure 8. At a compressive strength of $20.17 \mathrm{MPa}$, thermal conductivity coefficient of $1.073 \mathrm{~W} /(\mathrm{m} \mathrm{K})$ was obtained by $\mathrm{S} 1$ specimen having the ratio of $400 \mathrm{dm}^{3}$ of alkali activator. Furthermore, the lowest thermal conductivity coefficient of $0.822 \mathrm{~W} /(\mathrm{m} \mathrm{K})$ was reached at a compressive strength of $3.68 \mathrm{MPa}$ for S8A. Unlike strength, thermal conductivity coefficients were in a good agreement with a relationship between the bulk density of the specimens. In general the compressive strength, bulk density and thermal conductivity properties had direct relationship [34]. Albayrak et al [35] also reported that the compressive strength and the thermal conductivity values were reduced with decrease of bulk density.

The specimens were used in oven dry state for determination of thermal conductivity coefficients. Because thermal conductivity increases in accordance with the amount of moisture in specimens [36, 37]. In spite of having low bulk density values, specimens containing $\mathrm{Al}$ particles and high alkali activator content had slight lower thermal conductivity coefficients due to larger interconnected pore structure in the matrix.

The waste aluminium particles is illustrated in figure 9. As shown, Al particles had a shape like sheet and their sizes were mostly larger than $1 \mathrm{~mm}$. Structure of specimen having $\mathrm{Al}$ particles with high alkali activator content was investigated using optical imaging microscopy, which is shown in figure 10. Some continuous and isolated voids in the specimens containing Al-particles were found to be relatively larger than those of without Al particles. However, these voids were irregular shaped and were found to be connected with each other. This is also the reason of less amount of reduction in thermal conductivity as compared to that in strength for the specimens containing $\mathrm{Al}$ particles with high alkali activator content. This observation indicates that as-received waste aluminium particles could not be used properly without applying milling process.

\section{Conclusions}

The following conclusions are drawn from the results.

- With an increase in alkali content, bulk density, thermal conductivity, flexural and compressive strength generally decreased while water absorption increased owing to the specimens having higher porosity as compared to specimens with low alkali content.
- Open porosity was formed through the outer part of the specimens owing to the coarse size of Al-particles used. With the addition of Al-particles, substantial difference was not observed due to the pore structure.

- A relationship between the bulk density values and thermal conductivity coefficients of the specimens was observed.

- Mechanical properties increased with addition of silica fume and calcium hydroxide up to a certain level, then a decrease in strength took place. This variation in strength (since the alkali activator content was kept constant) was entirely due to the use of silica fume and calcium hydroxide in different volumetric ratios.

\section{References}

[1] Zhang H Y, Kodur V, Wu B, Cao L and Wang F 2016 Thermal behavior and mechanical properties of geopolymer mortar after exposure to elevated temperatures. Constr. Build. Mater. 109: 17-24

[2] Lee N K and Lee H K 2015 Reactivity and reaction products of alkali-activated, fly ash/slag paste. Constr. Build. Mater. 81: 303-312

[3] Liew Y M, Kamarudin H, Mustafa Al Bakri A M, Binhussain M, Luqman M, Khairul Nizar I, Ruzaidi C M and Heah C Y 2011 Influence of solids-to-liquid and activator ratios on calcined kaolin cement powder. Phys. Procedia 22: 312-317

[4] Boonserm K, Sata V, Pimraksa K and Chindaprasirt P 2012 Improved geopolymerization of bottom ash by incorporating fly ash and using waste gypsum as additive. Cem. Concr. Compos. 34: 819-824

[5] Yunsheng Z, Wei S, Qianli C and Lin C 2007 Synthesis and heavy metal immobilization behaviors of slag based geopolymer. J. Hazard. Mater. 143: 206-213

[6] Okoye F N, Durgaprasad J and Singh N B 2016 Effect of silica fume on the mechanical properties of fly ash basedgeopolymer concrete. Ceram. Int. 42: 3000-3006

[7] Kockal N U 2013 Effects of elevated temperature and recuring on the properties of mortars containing industrial waste materials. Iran. J. Sci. Technol. Trans. Civ. Eng. 37(C1): 67-76

[8] Zhang Z, Zhang B and Yan P 2016 Hydration and microstructures of concrete containing raw or densified silica fume at different curing temperatures. Constr. Build. Mater. 121: 483-490

[9] Lei D-Y, Guo L-P, Sun W, Liu J, Shu X and Guo X-L 2016 A new dispersing method on silica fume and its influence on the performance of cement-based materials. Constr. Build. Mater. 115: 716-726

[10] Kockal N U 2015 Behavior of mortars produced with construction wastes exposed to different treatments. Indian J. Eng. Mater. Sci. 22: 203-214

[11] Kockal N U and Turker F 2007 Effect of environmental conditions on the properties of concretes with different cement types. Constr. Build. Mater. 21: 634-645 
[12] Wu Z, Shi C and Khayat K H 2016 Effect of silica fume content on microstructure development and bond to steel fiber in ultrahigh strength cement-based materials (UHSC). Cem. Concr. Compos. 71: 97-109

[13] Ramana G V, Potharaju M, Mahure N V and Ratnam M 2013 Study on long term strength development and durability of multi blended concretes containing fly ash and silica fume. Int. J. Emerging Technol. Adv. Eng. 3: 599-608

[14] Kockal N U, Beycan O and Gulmez N 2017 Physical and mechanical properties of silica fume and calcium hydroxide based geopolymers. Acta Phys. Pol. A. 131: 530-533

[15] Chindaprasirt P, Paisitsrisawat P and Rattanasak U 2014 Strength and resistance to sulfate and sulfuric acid of ground fluidized bed combustion fly ash-silica fume alkali-activated composite. Adv. Powder Technol. 25: 1087-1093

[16] Dutta D, Thokchom S, Ghosh P and Ghosh S 2010 Effect of silica fume additions on porosity of fly ash geopolymers. ARPN J. Eng. Appl. Sci. 5: 74-79

[17] Mijarsh M J A, Megat Johari M A and Ahmad Z A 2015 Compressive strength of treated palm oil fuel ash based geopolymer mortar containing calcium hydroxide, aluminum hydroxide and silica fume as mineral additives. Cem. Concr. Compos. 60: 65-81

[18] Yang K H, Cho A R and Song J K 2012 Effect of waterbinder ratio on the mechanical properties of calcium hydroxide-based alkali-activated slag concrete. Constr. Build. Mater. 29: 504-511

[19] Vargas A S, Dal Molin D C C, Masuero Â B, Vilela A C F, Castro-Gomes J and de Gutierrez R M 2014 Strength development of alkali-activated fly ash produced with combined $\mathrm{NaOH}$ and $\mathrm{Ca}(\mathrm{OH})_{2}$ activators. Cem. Concr. Compos. 53: 341-349

[20] Reig L, Soriano L, Borrachero M V, Monzó J and Payá J 2014 Influence of the activator concentration and calcium hydroxide addition on the properties of alkali-activated porcelain stoneware. Constr. Build. Mater. 63: 214-222

[21] Alonso S and Palomo A 2001 Alkaline activation of metakaolin and calcium hydroxide mixtures: influence of temperature, activator concentration and solids ratio. Mater. Lett. 47: 55-62

[22] ASTM C 29-97 1997 Standard test method for bulk density (unit weight) and voids in aggregate. American Society for Testing and Materials, Philadelphia

[23] TS 3530 EN 933-1 1999 Agregaların geometrik özellikleri için deneyler bölüm 1: Tane büyüklüğü dağılımı tayinieleme metodu. Türk Standartları Enstitüsü, Ankara

[24] ASTM C 642-13 2013 Standard test method for density, absorption, and voids in hardened concrete. American Society for Testing and Materials, Philadelphia
[25] ASTM C 177-13 2013 Standard test method for steady-state heat flux measurements and thermal transmission properties by means of the guarded-hot-plate apparatus. American Society for Testing and Materials, Philadelphia

[26] TS EN 1015-11 2000 Methods of test for mortar for masonry Part 11: Determination of flexural and compressive strength of hardened mortar. Turkish Standards Institution, Ankara (In Turkish)

[27] Thokchom S, Ghosh P and Ghosh S 2009 Effect of water absorption, porosity and sorptivity on durability of geopolymer mortars. ARPN J. Eng. Appl. Sci. 4: 28-32

[28] Smilauer V, Škvára F, Němeček J and Hlaváček P 2010 Application of micromechanics on alkali-activated materials. Adv. Sci. Technol. 69: 75-85

[29] Thakur R N and Ghosh S 2009 Effect of mix composition on compressive strength and microstructure of fly ash based geopolymer composites. ARPN J. Eng. Appl. Sci. 4: 68-74

[30] Patankar S V, Jamkar S S and Ghugal Y M 2013 Effect of water-to-geopolymer binder ratio on the production of fly ash based geopolymer concrete. Int. J. Adv. Technol. Civ. Eng. 2: 79-83

[31] Rashad A M and Khalil M H 2013 A preliminary study of alkali-activated slag blended with silica fume under the effect of thermal loads and thermal shock cycles. Constr. Build. Mater. 40: 522-532

[32] Rattanasak U and Chindaprasirt P 2015 Properties of alkali activated silica fume- $\mathrm{Al}(\mathrm{OH})_{3}$-fluidized bed combustion fly ash composites. Mater. Struct. 48: 531-540

[33] Garcia-Lodeiro I, Palomo A, Fernández-Jiménez A and Macphee D E 2011 Compatibility studies between N-A-S-H and $\mathrm{C}-\mathrm{A}-\mathrm{S}-\mathrm{H}$ gels. Study in the ternary diagram $\mathrm{Na}_{2} \mathrm{O}$ $\mathrm{CaO}-\mathrm{Al}_{2} \mathrm{O}_{3}-\mathrm{SiO}_{2}-\mathrm{H}_{2} \mathrm{O}$. Cem. Concr. Res. 41: 923-931

[34] Wongkeo W, Thongsanitgarn P, Pimraksa K and Chaipanich A 2012 Compressive strength, flexural strength and thermal conductivity of autoclaved concrete block made using bottom ash as cement replacement materials. Mater. Des. 35: 434-439

[35] Albayrak M, Yorukoglu A, Karahan S, Atlihan S, Aruntas H Y and Girgin I 2007 Influence of zeolite additive on properties of autoclaved aerated concrete. Build. Environ. 42: $3161-3165$

[36] Gomes M G, Flores-Colen I, Manga L M, Soares A and de Brito J 2017 The influence of moisture content on the thermal conductivity of external thermal mortars. Constr. Build. Mater. 135: 279-286

[37] Belkharchouche D and Chaker A 2016 Effects of moisture on thermal conductivity of the lightened construction material. Int. J. Hydrogen Energy 41: 7119-7125 